\title{
Titanium tetrachloride burns to the eye
}

\author{
D K Chitkara, B J McNeela
}

\begin{abstract}
We present eight cases of chemical burns of the eyes from titanium tetrachloride, an acidic corrosive liquid. However it causes severe chemical burns which have a protracted course and features more akin to severe alkali burns. Injuries related to titanium tetrachloride should be treated seriously and accordingly appropriate management is suggested.
\end{abstract}

The effect of chemical injuries to the eye is well documented. ${ }^{1-3}$ Titanium tetrachloride $\left(\mathrm{TiCl}_{4}\right)$ is an intermediate product in the manufacture of the widely used pigment titanium dioxide $\left(\mathrm{TiO}_{2}\right) \cdot \mathrm{TiO}_{2}$ is a white inert pigment used in the manufacture of paints, linoleum, lacquers, leather, inks, rubber, soaps, textiles, ceramics, plastics, and numerous other consumer, commercial, and building products. It is also used in adhesives, cellophane, cosmetics, paper products, and to whiten salads and spreads.

Titanium tetrachloride is a corrosive pale yellow liquid which is acidic. When exposed to the atmosphere it gives off dense white fumes composed of hydrogen chloride mist and solid particles of hydrolysed titanium compounds. ${ }^{4}$ Major chemical burns caused by $\mathrm{TiCl}_{4}$ do not follow the pattern of injury and healing that would normally follow injury by a corrosive acid - for example, hydrochloric acid or sulphuric acid. Instead, to some degree the severity of injury is consistent with an injury caused by a strong alkali - for example, ammonia or sodium hydroxide.

We present eight cases of $\mathrm{TiCl}_{4}$ burns to the eye which have been seen in our casualty department over the past 4 years, four of which illustrate this compound's propensity for severe tissue damage. The cases are described in detail and summarised in Table 1. Thoft's classification $^{5}$ has been used to grade the injuries.

\section{Case reports}

CASE 1 liquid in his left eye. On examination the vision was reduced to $6 / 36+1$ and there were mild corneal and inferior conjunctival epithelial defects in his left eye. The patient was treated with betamethasone with neomycin and atropine drops. He made an uneventful and complete recovery and was discharged 2 days later.

rtment of Ophthalmology, North Riding Infirmary, Middlesbrough, Cleveland TS1 5JE

D K Chitkara B J McNeela

Correspondence to: B J McNeela.

Accepted for publication 21 February 1992

\section{CASE 2}

A 39-year-old man was accidently sprayed on his face by $\mathrm{TiCl}_{4}$ from a high pressure pipe. Fortunately he was wearing goggles and only suffered Thoft grade I burns to both eyes. He
A 20-year-old man accidently splashed $\mathrm{TiCl}_{4}$

was treated with topical steroids and antibiotics and made an uneventful recovery within 3 days. $\mathrm{He}$ also suffered severe burns to both his calves and face, requiring split skin grafts.

\section{CASE 3}

A 19-year-old man accidentally splashed a small amount of $\mathrm{TiCl}_{4}$ onto both eyes. He suffered mild corneal punctate stains which recovered completely and uneventfully within 2 days following treatment with chloramphenicol eye ointment.

\section{CASE 4}

A 46-year-old man was accidentally sprayed with $\mathrm{TiCl}_{4}$ liquid from a high pressure pipe while opening a valve. He suffered Thoft grade 4 corneal and conjunctival burns, especially in the right eye. Intensive treatment with topical steroids and antibiotics was given. The left eye healed rapidly within 3 days. The right eye subsequently developed a sterile hypopyon and raised intraocular pressure. This resolved slowly over a 17 day period. A small corneal epithelial defect remained. Healing was further complicated by upper and lower lid entropion and trichiasis. This progressed to corneal scarring and vascularisation over a 6 week period with persistently raised pressure. Vision deteriorated over several months to perception of light and the eye became totally blind and painful within 2 years. The patient left the district but is known to have undergone enucleation of this eye.

\section{CASE 5}

A 42-year-old man accidentally sprayed $\mathrm{TiCl}_{4}$ onto both eyes. The left eye suffered Thoft grade 1 burns, which settled quickly within 3 days. The right eye, however, had Thoft grade 4 corneal and conjunctival burns with conjunctival ischaemia and anterior uveitis. Lens opacity was noted within 3 days. A sterile hypopyon and severe corneal stromal lysis developed in 2 months. This progressed to right corneal perforation despite intensive therapy. The perforation was initially treated with cyanoacrylate glue and a lamellar patch graft. Several attempts at entropion and trichiasis correction were made. The right eye became blind and irritable, and was later enucleated.
CASE 6

A 42-year-old man accidentally sprayed $\mathrm{TiCl}_{4}$ liquid into both eyes and face. The right eye was affected more severely. On presentation there was a large central corneal epithelial defect together with stromal oedema. There was severe 
Table 1 Summary of cases reported

\begin{tabular}{|c|c|c|c|c|c|c|c|}
\hline $\begin{array}{l}\text { Case } \\
\text { no }\end{array}$ & Age & Sex & Laterality & Initial VA & $\begin{array}{l}\text { Severity } \\
\text { grade }\end{array}$ & Complications & Final VA \\
\hline 1 & 20 & Male & \multirow{5}{*}{$\begin{array}{l}\text { Left } \\
\text { Left } \\
\text { Right } \\
\text { Left } \\
\text { Right } \\
\text { Left } \\
\text { Right }\end{array}$} & \multirow{5}{*}{$\begin{array}{l}6 / 36 \\
6 / 6 \\
6 / 9\end{array}$} & \multirow{5}{*}{$\begin{array}{l}2 \\
1 \\
1 \\
1 \\
1 \\
2 \\
3\end{array}$} & None & \multirow{5}{*}{$\begin{array}{l}6 / 6 \\
6 / 9\end{array}$} \\
\hline 2 & 39 & Male & & & & $\begin{array}{l}\text { None } \\
\text { None }\end{array}$ & \\
\hline 3 & 19 & Male & & & & None & \\
\hline 4 & 46 & Male & & & & $\begin{array}{l}\text { None } \\
\text { None }\end{array}$ & \\
\hline & & & & & & $\begin{array}{l}\text { Hypopyon, glaucoma, entropion, trichiasis, } \\
\text { corneal scarring and vascularisation, enucleation }\end{array}$ & \\
\hline 5 & 42 & Male & $\begin{array}{l}\text { Left } \\
\text { Right }\end{array}$ & $\begin{array}{l}6 / 6 \\
\mathrm{CF}\end{array}$ & $\begin{array}{l}1 \\
3\end{array}$ & $\begin{array}{l}\text { None } \\
\text { Cataracts, hypopyon, corneal perforation, entropion, } \\
\text { trichiasis }\end{array}$ & $\begin{array}{l}\text { 6/6 } \\
\text { NPL }\end{array}$ \\
\hline 6 & 42 & Male & $\begin{array}{l}\text { Left } \\
\text { Right }\end{array}$ & $\begin{array}{l}6 / 60 \\
6 / 60\end{array}$ & 2 & $\begin{array}{l}\text { None } \\
\text { Corneal neovascularisation, symblepharon, entropion, } \\
\text { trichiasis and pseudoterygium }\end{array}$ & $\begin{array}{l}6 / 60 \\
\mathrm{CF}\end{array}$ \\
\hline 7 & 21 & Male & Right & & 2 & None & \\
\hline 8 & 32 & Male & $\begin{array}{l}\text { Left } \\
\text { Right }\end{array}$ & Unobtainable & $\begin{array}{l}4 \\
3\end{array}$ & Pulmonary oedema & $\begin{array}{l}\text { Died } 2 \text { weeks } \\
\text { after injury }\end{array}$ \\
\hline
\end{tabular}

$\mathrm{CF}=$ counting fingers $\mathrm{NPL}=$ no perception of light.

chemosis and ischaemia of conjunctiva inferonasally. The eye settled slowly and despite intensive therapy the patient developed corneal vascularisation and cicatricial changes in both upper and lower fornices within a matter of 3-4 weeks. Six months after injury he was noted to have symblepharon formation affecting the inferomedial fornix together with a cicatricial entropion and large pseudopterygium covering the nasal cornea which involved the visual axis. Subsequent treatment has included dissection of pseudopterygium with ' $Z$ ' plasty of conjunctiva and a free conjunctival graft from upper fornix plus a lamellar corneal graft in May 1988. In March 1989 he had a buccal membrane graft to medial fornix and tarsal entropion correction. This patient is currently under review and further corneal surgery is planned.

CASE 7

A 21-year-old man received an accidental splash of $\mathrm{TiCl}_{4}$ in his right eye. After thorough irrigation he was found to have signs of a Thoft grade 2 chemical burn. There were defects of the inferior corneal and conjunctival epithelium. The epithelial defects healed quickly, but for the next 6 months there was persistent vascular engorgement of the conjunctiva. The response to topical steroid administration appeared to be good, but there was evidence of non-compliance and eventually the inflammation settled after subconjunctival steroid was injected. This patient suffered no permanent visual loss. He was examined 2 years after the injury and no significant abnormality was found.

CASE 8

This patient was admitted to the intensive care unit of a local district general hospital after he was splashed over the whole of his body with $\mathrm{TiCl}_{4}$. This occurred when a large quantity of the chemical was released accidentally at a nearby chemical works. He suffered extensive burns to facial skin, nasopharynx, and larynx. Both eyes were severely injured. The corneas were thick and opaque and there was extensive swelling of the bulbar conjunctiva and episclera. Over the following 14 days there was some clearing of the corneal opacification in the right eye, but the left eye did not improve. It quickly became apparent that this patient had suffered severe injury to the lungs by inhalation of $\mathrm{TiCl}_{4}$ fumes. There was progressive deterioration in pulmonary compliance and it became impossible to maintain adequate oxygenation. He died 2 weeks after the chemical injury. Unfortunately the eyes were not retained at necropsy and histological examination was not performed.

\section{Discussion}

Titanium tetrachloride reacts extremely vigorously with water in any form, including perspiration on skin, moisture in air, tears, etc, liberating large quantities of heat. It is postulated that the initial thermal burn exposes the deeper tissues to the effect of hydrochloric acid thereby producing very severe burns. Its effect on skin and lungs are well known. ${ }^{67}$ Action to deal with eye injury from $\mathrm{TiCl}_{4}$ must be swift. Excess liquid be wiped away immediately with a clean dry cloth to reduce its interaction with water. The eye should then be washed continuously with copious quantities of water for at least 30 minutes, ensuring that irrigation is complete by holding the eyelids open. ${ }^{8-10}$ Any solid particles retained under the eyelids must be removed from the eye. All such injuries should then be referred to an ophthalmologist without delay.

After transfer to the hospital irrigation should be repeated. Subsequent management depends on the severity of injury. In instances where a high pressure spray is involved the injury is likely to be very severe due to the combined effects of thermal and strong acid burns. These require intensive topical steroids and ascorbate, topical antibiotics and mydriatics, and oral ascorbate. The examining ophthalmologist should look for cutaneous burns and should be aware of possible respiratory tract injury if the vapour has been inhaled.

The workforce must be made aware of the potential dangers of this chemical. The locations of an eyewash station must be clearly marked around the factory. All workers handling this chemical or working near pipes carrying this chemical should be advised to wear protective clothing and goggles at all times. All the cases, except case 2 , in our study were not wearing protective eyewear at the time of injury. In this 
respect our findings have been conveyed to the manufacturers and efforts have been made to improve safety. No further cases have been referred for at least 1 year.

I Wright $P$. The chemically injured eye. Trans Ophthalmol Soc UK 1982; 102: 85-7.

2 Pfister RR. Chemical injuries of the eye. Ophthalmology 1983; 90: 1246-54.

Mechanisms of chemical injuries. Duke Elder system of ophthalmology, vol XIV injuries, Part 2: 1098.

4 The metallic corrosives - titanium. Duke Elder system of ophthalmology, vol XIV Injuries, Part 2: 1098.

5 Thoft RA, Friend J, Kenyon KR. International ophthalmology clinics. Boston: Little Brown, 1979; 19: No 2.
6 DiBenedetta R, Park T, Morgan K, Colmers R, Sherman E. Diffuse endobronchial polyposis following a titanium
tetracholoride inhalation injury. Am Rev Resp Dis 1984; 130: tetrach

7 Epidemiologic study of lung cancer, chronic respiratory disease etc in workers exposed to titanium dioxide and titanium tetrachloride. Medical Division, Du Pont de Nemours, 1987.

8 Nelson JD, Kopietz LA. Chemical injuries to the eyes. Emergency, intermediate and long term care. Postgrad Med 1987; 81: 62-6, 69-71, 75 .

9 Burns FR, Paterson CA. Prompt irrigation of chemical eye injuries may avert severe damage. Occup Health Saf 1989; 58: 33-6.

10 Saari KM, Leinonen J, Aine E. Management of chemical eye injuries with prolonged irrigation. Acta Ophthalmol (Kbh) 1984; 161: 52-9. 